\title{
On-farm Evaluation and System Productivity of Wheat-Jute-T. aman Rice Cropping Pattern in Char Area of Bangladesh
}

\author{
Uttam Kumer Sarker $^{1}$, Sirajam Monira ${ }^{1} \&$ Md. Romij Uddin ${ }^{1}$ \\ ${ }^{1}$ Department of Agronomy, Bangladesh Agricultural University, Mymensingh, Bangladesh \\ Correspondence: Md. Romij Uddin, Department of Agronomy, Bangladesh Agricultural University, Mymensingh, \\ Bangladesh. Tel: 880-178-037-0135. E-mail: romijagron@bau.edu.bd
}

Received: January 10, 2020 Accepted: February 17, 2020 Online Published: March 11, 2020

\begin{abstract}
A study was conducted for two consecutive years to determine the yield and system productivity of two cropping patterns viz. IP: (Wheat - Jute - T. aman) improved pattern with improved management practices and FP: (Fallow - Fallow - T. aman) farmers' pattern with farmers' management practices in char (adjacent to the river) area of Netrakona region of Bangladesh. The experimentswere laid out in a randomized complete block design with 10 dispersed replications at a farmer's field. The two years mean data showed that the total component crops of IP (wheat-jute-T. aman rice) gave higher yield as well as a by-product in both years. The higherrice equivalent yield (10.52 and 10.63 tha $\left.^{-1}\right)$, production efficiency $\left(30.13\right.$ and $30.43 \mathrm{~kg} \mathrm{ha}^{-1}$ day $\left.^{-1}\right)$ land-use efficiency $(87.13$ and $87.84 \%$ )and benefit cost ratio (2.15 and 2.11) pointed out the dominance of the improvedpattern over the farmer's existing pattern. Higher rice equivalentyield signified that improved cropping pattern (Wheat - Jute -T. aman) could be appropriate in Netrakona region for rising crop productivity andcropping intensity. The higher production efficiency, land use efficiency and benefit cost ratio indicated the superiority of the improved pattern over the farmers' practices.It can be concluded that farmers of the char area of the Netrakona region might follow wheat (var. BARI Gom-26) - jute (var. O-9897) - T. aman (var. BRRI dhan49) cropping system in char land for higher productivity and profitability.
\end{abstract}

Keywords: Char land, agronomic performance, land use efficiency, production potential, economic return

\section{Introduction}

Changes in climate, population expansion, food scarcity, poverty, starvation, accelerated land cover change and environmental degradation are the foremost challenges of the 21 st century (Neamatollahi et al., 2017).In the world about 1 billion people keep on hungry every day due to the inadequate food supply and thisnumber will riseup to 2 billion by 2050 (FAOSTAT, 2014). For the developing countries of Asia and Africa, this situation insists on the increasing momentum in agricultural production with more than 70 percent increase in the coming decades (Neamatollahiet al., 2017). To enhance agriculture productivity improved cropping patterns and better management practices are essential. Land and water resources are becoming very limited due to the rapid change in population and urbanization. Subsequently, to determine the optimal use of the available resources improved cropping pattern has been developed for exploiting the net profit subjected to some limitations (Osama et al., 2017).

Bangladesh is aheavily populated countryand itspopulation is about 200 million. Besides, the cultivable land is in a decreasing trend and it is about $1 \%$ per year. Bangladesh covers about $14.84 \mathrm{M} \mathrm{ha}$ (million hectares) of total land and among this $3.74 \mathrm{M}$ ha ( $25 \%$ of the total) is not appropriate for cultivation due to deployment for urban areas, commercial buildings, countryside homesteads, roads etc (Quasem, 2011). Bangladesh also suffersfrequently from differentnormaldisasters (Haq et al., 2012; Khatun et al., 2016; Islam et al., 2017a), that may get worse in the long runas a result of climate change (Hossain et al., 2016; Rokonuzzaman et al., 2018). Therefore, to declare food security for increasing people in the future we need to produce huge food on a reduced amount of land (Islam et al., 2015a\&b). Two techniques need to be adopted to achieve this issue. Firstlyit may be by increasing cropping intensity by producing more crops on the similar land during whole year and secondlyby augmenting productivity of each crops (FAOSTAT, 2013; Dobermann et al., 2013; Datta et al., 2015; Ladha et al., 2016; Datta et al., 2017; Islam et al., 2017b). Bangladesh agriculture mostly consists of rice basedcropping patterns (Haque, 1998). Different cropping pattern are available in Bangladesh and abroad and these are well reported. (Soniand Kaur, 1984; Malavia et al., 1986; Khan et al., 2005; Ferdous et al., 2011;Anowaret al., 2012;Nazrul et al., 2013; Anowar et al., 2015; Khatun et al.,2016 and Anwar et al., 2017) where a supplementary crops may be incorporated without 
substituting the accessible ones for significantenhancement of in general productivity andincome of the farmers (Islam, 2012a \&b).

The char areas of the Netrakona region occupy 8547 acre of land out of 78915 acres and it is dominated by FallowFallow- T. aman rice (rainfed rice) cropping pattern. A hugepart remains uncultivated for an extensive time after the harvest of T. aman rice such as BR11 (100-110 days main field duration ). This is mainly due to water shortage after T. aman harvest and waterlogging condition during monsoon.Only rice production is not sufficient and profitable for the farmers of this area. So an adaptation of alternative cropping patterns to support the most efficient use of the limited natural resources is a prime need for recent days. Wheat is such a promising crop, which can be easily grown after T. aman harvest with residual soil moisture and requires less water in some cases.Jute is a fiber crop that can be grown after harvesting of Wheat during monsoon. So the proposed cropping pattern of this area may be wheat-jute- T. aman. Considering these observations, the present study was designed to introduce to utilize uncultivated land properly during rabi (winter season) and kharif I (monsoon) season minimizing water stress and waterlogging condition with improved cropping pattern Wheat-Jute-T. aman as well as increase the production and meet the demand of that area.

\section{Material and Methods}

\subsection{Site Description}

The experiments were done in farmer's field under the char areas of Netrakonawhich is located in between $24^{\circ} 34^{\prime}$ and $25^{\circ} 12^{\prime}$ north latitudes and between $90^{\circ} 00^{\prime}$ and $91^{\circ} 07^{\prime}$ east longitudes of Bangladesh during two consecutive years 2017 and 2018. The experimental site (Netrakona) is under a moist subtropical monsoon type of climate. The mean minimum and maximum temperature and rainfall for the experimental period are shown in Fig. 1. The physicochemical properties of the soil before the beginning of the experiment are shown in Table 1.

\subsection{Experimental Design and Treatments}

Treatments consisting of two cropping patterns viz. FP: farmers' pattern (Fallow - Fallow - T.aman) and IP: improved pattern (Wheat - Jute - T. aman) by incorporation of recent high yielding varieties of Jute, T. amanrice andwheat. Modern management practices were used for crop production. The experiments were set up using a randomized complete block design with 10 dispersed replications. The individual plot size was $100 \mathrm{~m}$. The improved pattern was used in one plot andfarmer's pattern was practiced in other plots. Wheat var. BARI Gom26 and jute var. O-9897 were introduced in the improved pattern against the fallow period. The variety BRRI dhan49 of T. aman rice was introduced instead of BR11.

\subsection{Crop Management}

The agronomic practices and cultural operation for crop production under improved and farmers' practices are presented in Table 2. All field operation and management practices of both farmers' and improved patterns were closely monitored and the data were recorded for agro-economic performance.

\subsection{Data Collection}

Ten plants were chosen from every plot randomly at maturityfor data collection and yield of wheat, T. aman rice and jute were calculated. Plot-wise yield for each crop was determined on an area basis $\left(\mathrm{kg} \mathrm{ha}^{-1}\right)$. Agronomic performance viz. rice equivalent yield, production efficiency, and land use efficiency were calculated.

\subsection{Estimation of Rice Equivalent Yield (REY)}

Based on the existing market price of the individual crops, the yield of every single crop was converted into rice equivalent yield for making the relationship between crop sequences (Verma and Modgal, 1983). The gross return, net return and benefit cost ratio were also evaluated based on the market price of each produces.

Rice equivalent yield $\left(\right.$ tha $\left.^{-1}\right)=\frac{\text { Yield of individual crop } \times \text { Market price of that crop }}{\text { Market price of rice }}$

\subsection{Estimation of Production Efficiency}

Production efficiencywas determinedas $\mathrm{kg} \mathrm{ha}^{-1} \mathrm{day}^{-1}$ by the whole production in a cropping series divided by the entiretime of crops in that sequence (Tomer and Tiwari, 1990).

Production efficiency $=\frac{\mathrm{Y} 1+\mathrm{Y} 2+\mathrm{Y} 3}{\mathrm{~d} 1+\mathrm{d} 2+\mathrm{d} 3}$

Where, $Y_{1}=$ Yield of $1^{\text {st }}$ crop and $d_{1}=$ Duration of $1^{\text {st }}$ crop of the pattern 


$$
\begin{aligned}
& Y_{2}=\text { Yield of } 2^{\text {nd }} \text { crop and } d_{2}=\text { Duration of } 2^{\text {nd }} \text { crop of the pattern } \\
& Y_{3}=\text { Yield of } 3^{\text {rd }} \text { crop and } d_{3}=\text { Duration of } 3^{\text {rd }} \text { crop of the pattern }
\end{aligned}
$$

\subsection{Determination of Land Use Efficiency}

For determination of land use efficiencytotal length of individual crop in a sequence is divided by 365 days (Tomer and Tiwari, 1990). It is calculated by following formula.

Land use efficiency $=\frac{d 1+d 2+d 3}{365} \times 100$

Where $d_{1}, d_{2}$ and $d_{3}$ the duration of $1^{\text {st }}, 2^{\text {nd }}$ and $3^{\text {rd }}$ crop of the pattern

\subsection{Benefit Cost Ratio (BCR)Analysis}

Average data of two crop cycles were calculated for the economic assessment of two dissimilar cropping cycles. The production expenses of these crops were determined by calculating the material and non-materialcost of production. Using the prevailing average market prices for the yield of these crops in Bangladesh the gross return was calculated. Gross margin was designed by deducting total expenses from the gross income which was worked out by dividing the gross income with total expenditure. Benefit cost ratio (BCR)was calculated with the following formula.

Benefit Cost Ratio $(\mathrm{BCR})=\frac{\text { Gross return }}{\text { Total variable cost of production }} \times 100$

\section{Results and Discussion}

\subsection{Grain/Fibreyield of the cropping patterns}

Grain/fibreyield of different cropping pattern have been presented in Table 3. It was revealed that the cropping pattern wheat-jute-T. aman rice under improved practices (IP) gave higher yield and by-product during both years. The reason behind improvement of yield inIP was theuse of variety with modern cultivation technique for the component crops. Higher wheat yield was documented during $2017\left(3.02\right.$ tha $\left.^{-1}\right)$ and $2018\left(3.05\right.$ tha $\left.^{-1}\right)$ with an average yield of 3.04tha ${ }^{-1}$. In improved pattern higher jute yield was recorded during 2017 (2.89tha $\left.{ }^{-1}\right)$ and 2018 $\left(2.93\right.$ tha $\left.^{-1}\right)$. T. aman rice yield was different in both patterns and higher yield (3.23 and 3.25 tha $^{-1}$ in 2017 and 2018) was recorded in farmers' practice over improved (3.13 and 3.15 tha $\left.^{-1}\right)$ due to single crop cultivation in farmers' practice. Khatun et al. (2016) and Khan et al. (2006) conducted experiments and found more yield in single crop cultivation than improved cropping pattern for a specific crop. 


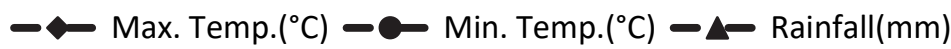

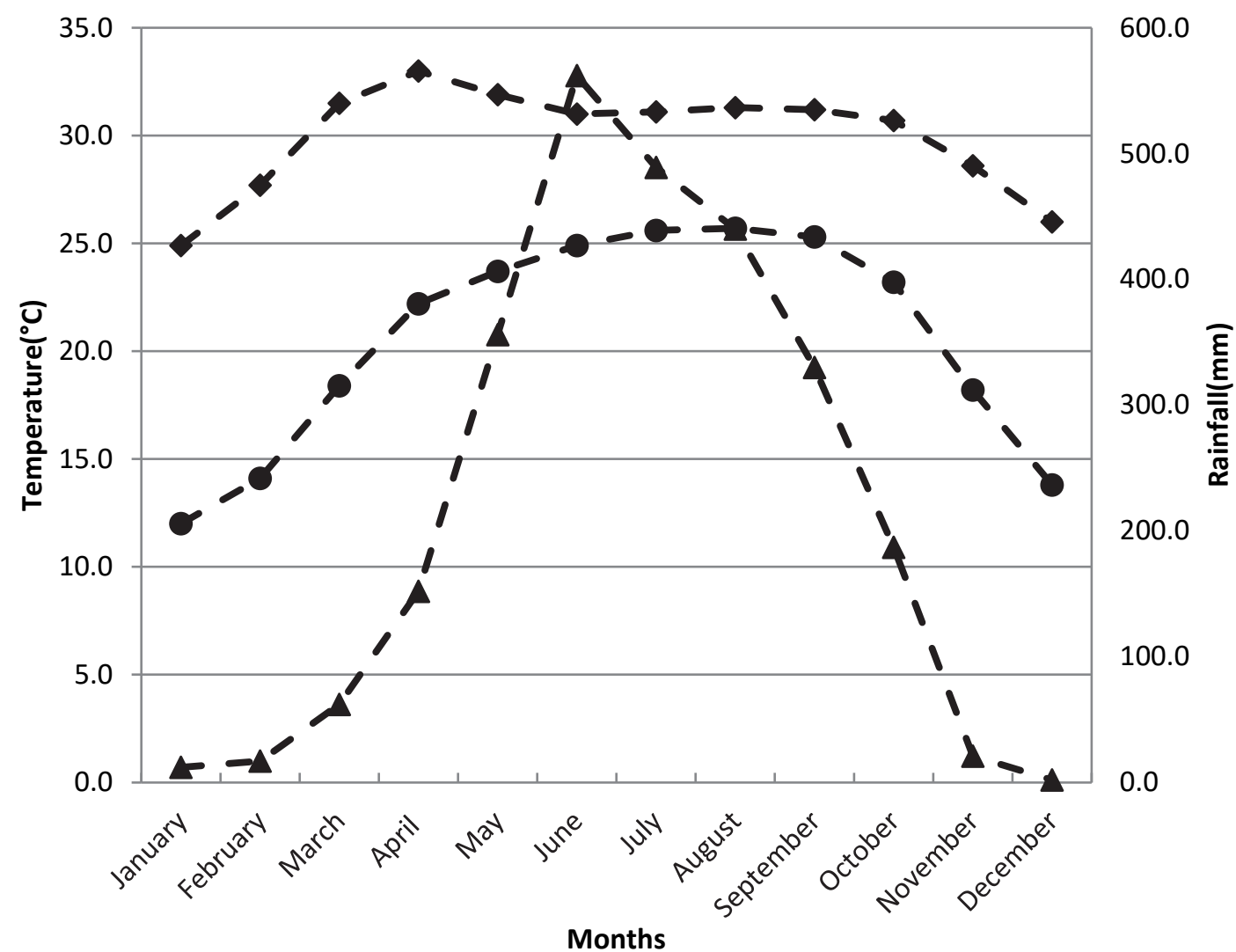

Figure 1. Average maximum temperature, minimum temperature and annual rainfall during the cropping seasons 2017 and 2018

\subsection{By-product Yield of the Cropping Patterns}

By-product yield of the component crops was measured from biomass yield (Table 3). Higher amount of total byproduct yield of the component crops (14.1 and $14.2 \mathrm{t} \mathrm{ha}^{-1}$ in 2017 and 2018) produced in the improved cropping pattern than that of the farmers' pattern $\left(4.26\right.$ and $\left.4.30 \mathrm{t} \mathrm{ha}^{-1}\right)$. Nazrul (2016) stated the reason behind the higher by-product yield of improved pattern than that of farmers' pattern and reason behind it is the incorporation of new variety with improved technologies for the component crops. Beside this the component crops wheat and jute of improved pattern produced high demandable as well as more profitable by-product whereas it was difficult for the farmers to sell the rice by-product (rice straw) in the local market with proper price.

\subsection{Rice Equivalent Yield}

Rice equivalent yield was higher in IPcompared to farmers' practice. The mean rice equivalent yield of IP was 10.58 tha $^{-1}$ and that of FPwas 3.24tha ${ }^{-1}$ (Table 4). This happened due to inclusion of high yielding variety BRRI dhan 49 instead of BR11 and extra two new cropsalong with modern cultivation techniques in the improved pattern increased the T.aman rice equivalent yield. Besides rice equivalent yield was higher in improved pattern due to superiormarket price of components crops in the IP. Rice equivalent yield was lower in the FP due to use of conventionalvariety and management practices. 
Table 1. Average of soil nutrient status of the experimental areas of Netrakona region during 2017 and 2018

\begin{tabular}{ll}
\hline Soil property & Values \\
\hline Soil texture & Sandy loam \\
$\mathrm{pH}-\mathrm{H}_{2} \mathrm{O}$ & 5.65 \\
$\mathrm{Ec}(\mu \mathrm{s} / \mathrm{cm})$ & 143 \\
Organic matter $(\%)$ & 1.51 \\
& \\
Total N $(\%)$ & 0.084 \\
Available P (ppm) & 33.66 \\
Available K (meq/100g) & 0.144 \\
Available S $(\mathrm{ppm})$ & 59.64 \\
\hline
\end{tabular}

\subsection{Production Efficiency}

Highest production efficiency (30.13 and $30.43 \mathrm{~kg}$ ha-1day-1) wasrecorded from IP inthe year of 2017 and 2018 , (Table 4). Mean production efficiency (30.28 kg ha-1 day-1)was higher in IP and lower (29.45kg ha-1day-1) in FP. Reddy (1997), Khan et al. (2006) and Nazrul et al. (2013) found that mean production efficiency wasalways superior in IP compared to FP. The higher production efficiency of improved cropping pattern indicated that the component crops remain in the field for long duration with higher yield under modern cultivation practices. On the other hand, the lowest production efficiency observed in FP wheretraditional management are used and indicated that cropsremained in the field for shorter time with lower yield under traditional system.

Table 2. Management practices of improved vs farmers' existing cropping pattern during 2017 and 2018

\begin{tabular}{|c|c|c|}
\hline Parameter & Farmers' pattern & Improved pattern \\
\hline Variety & T. aman (BR11) & $\begin{array}{l}\text { Wheat (BARI Gom 26)- Jute (O-9897)- T. aman (BRRI } \\
\text { dhan49) }\end{array}$ \\
\hline Date of sowing & 12-15 August & $\begin{array}{l}\text { Wheat 21-24 November (2017), Jute 4-8 April (2017) } \\
\text { and 2-4 April (2018), Aman 5-10 August (2017) and 5- } \\
8 \text { August (2018) }\end{array}$ \\
\hline Seed rate $\left(\mathrm{kg} \mathrm{ha}^{-1}\right)$ & $20-25$ & Wheat 120, Jute 7, Aman 25 \\
\hline Planting method & Line & Line for all crops \\
\hline Spacing (cm) & $20 \times 15$ & Wheat $30 \times 5$, Jute $20 \times 5$, Aman $25 \times 15$ \\
\hline $\begin{array}{l}\text { Fertilizer dose (N P K S } \\
\mathrm{Zn} \mathrm{kg} \mathrm{ha}^{-1} \text { ) }\end{array}$ & $92-24-60-8-0.5$ & $\begin{array}{l}\text { 120-30-60-15-1 (Wheat), 110-15-40-8-0.5 (Jute), 115- } \\
35-40-4-0.5 \text { (T.aman) }\end{array}$ \\
\hline Weeding & 1 & Wheat 1 ,Jute 2, T.aman 2 \\
\hline Irrigation & Rainfed & Rainfed \\
\hline Harvesting time (date) & 15-20 Nov & $\begin{array}{l}\text { 10-14 March, } 2018 \text {, 3-25 July (2017), } 20-22 \text { July (2018) } \\
\text { 10-15 November (2017), 15-18 Nov. (2018) }\end{array}$ \\
\hline Field duration (days) & $100-110$ & 110-115 (Wheat), 100-108(Jute), 90-95 (T.aman) \\
\hline
\end{tabular}

\subsection{Land Use Efficiency}

Land use efficiency is the efficient utilization of land in a cropping year and it mainly depends on crop duration. The average land-use efficiency of IP was $87.49 \%$ whereas it was $30.30 \%$ for FP (Table 4 ). This superior land use efficiency in IP was due to cultivation of wheat and jute in bare period that's why field was occupied by the crops for a longer period (300-318 days), whereas the farmers practice occupied the field for 100-110 days of the year. 
Table 3. Productivity of improved and farmers' existing patterns during 2017 and 2018

\begin{tabular}{llllllll}
\hline Year & Cropping & \multicolumn{3}{l}{ Grain/Fibre yield $\left(\mathrm{t} \mathrm{ha}^{-1}\right)$} & \multicolumn{3}{l}{ By product yield $\left(\mathrm{t} \mathrm{ha}^{-1}\right)$} \\
\cline { 2 - 7 } 2017 & pattern & Fallow/Wheat & Fallow/Jute & T.aman & Fallow/Wheat & Fallow/Jute & T.aman \\
& IP & 3.02 & 2.89 & 3.13 & 3.54 & 6.37 & 4.12 \\
2018 & FP & - & - & 3.23 & - & - & 4.26 \\
& IP & 3.05 & 2.93 & 3.15 & 3.59 & 6.42 & 4.15 \\
& FP & - & - & 3.25 & - & - & 4.30 \\
SE \pm & & 0.02 & 0.02 & 0.03 & 0.03 & 0.03 & 0.04 \\
Mean & IP & 3.04 & 2.91 & 3.14 & 3.57 & 6.39 & 4.14 \\
& FP & - & - & 3.24 & - & - & 4.28 \\
\hline
\end{tabular}

$\mathrm{IP}=$ Improved practice, $\mathrm{FP}=$ Framers' practice

\subsection{Cost Benefit Analysis}

Based on the existing market price during the crop season, cost and return analysis were done. From the economic point of view, IP showed its superiority over FP during both years. The average gross return of the IP was 277057.5Tk. ha-1which was $84.25 \%$ higher than that of FP (Table 5). Thecost of cultivation of IP (131707Tk. ha1) was superior toFP (85511 Tk. ha-1) due to higher labor and input cost. The net return was considerablysuperior in the IP (145600.5 Tk. ha-1) than FP (64184 Tk. ha-1). Inclusion of wheat and jute in these cropping systems during fallow season andincrement of system productivity results in increased gross margin. In the FP $126.85 \%$ supplementary net return was attained by adding $54.02 \%$ extra cost. The marginal benefit cost ratio was determined for both IP and FP. The results revealed that a higher benefit cost ratio (2.13) was found in IP over the FP (1.76). Farmers showed a highly positive response to cultivate jute and T. aman in this season and they opined that due to lack of knowledge they were not interested to grow Jute before as they experienced water logging conditions during monsoon. The farmers also added that the yield performances of the BARI Gom26, Jute (O-9897) and BRRI dhan 49 were acceptable. After harvest of T. amanrice, modern wheat variety (BARI Gom26) could easily be grown which doesn't hamper or delay jutecultivation. Jute can be easily be grown between wheatand T. aman rice.

Table 4. Rice equivalent yield, production efficiency and Land use efficiency of improved and farmers' existing patterns during 2017 and 2018

\begin{tabular}{|c|c|c|c|c|}
\hline Year & Cropping pattern & $\begin{array}{l}\text { Rice equivalent yield } \\
\left(\mathrm{t} \mathrm{ha}^{-1}\right)\end{array}$ & $\begin{array}{l}\text { Production efficiency } \\
\left(\mathrm{kg} \mathrm{ha}^{-1} \text { day }^{-1}\right)\end{array}$ & $\begin{array}{c}\text { Land use efficiency } \\
(\%)\end{array}$ \\
\hline \multirow[t]{2}{*}{2017} & IP & $10.52 b$ & $30.13 b$ & $87.13 \mathrm{~b}$ \\
\hline & FP & $3.23 \mathrm{c}$ & $29.36 \mathrm{~d}$ & $30.14 d$ \\
\hline \multirow[t]{2}{*}{2018} & IP & $10.63 \mathrm{a}$ & $30.43 a$ & $87.84 \mathrm{a}$ \\
\hline & FP & $3.25 \mathrm{c}$ & $29.54 \mathrm{c}$ & $30.45 \mathrm{c}$ \\
\hline \multirow{3}{*}{ Mean } & $\mathrm{SE} \pm$ & 0.04 & 0.05 & 0.06 \\
\hline & IP & 10.58 & 30.28 & 87.49 \\
\hline & FP & 3.24 & 29.45 & 30.30 \\
\hline
\end{tabular}

$\mathrm{IP}=$ Improved practice, $\mathrm{FP}=$ Framers' practice

Table 5. Cost benefit analysis of improved and farmers' existing patterns during 2017 and 2018

\begin{tabular}{clllll}
\hline Year & $\begin{array}{c}\text { Cropping } \\
\text { pattern }\end{array}$ & \multicolumn{1}{c}{$\begin{array}{c}\text { Gross return } \\
\left(\mathrm{Tk} \mathrm{ha}^{-1}\right)\end{array}$} & $\begin{array}{c}\text { Cost of cultivation } \\
\left(\mathrm{Tk} \mathrm{ha}^{-1}\right)\end{array}$ & $\begin{array}{c}\text { Gross margin } \\
\left(\mathrm{Tk} \mathrm{ha}^{-1}\right)\end{array}$ & BCR \\
\hline 2017 & IP & 283515 & 131957 & 151558 & 2.15 \\
& FP & 151290 & 85761 & 65529 & 1.76 \\
\multirow{2}{*}{ Mean } & IP & 270600 & 131457 & 139643 & 2.11 \\
& FP & 149445 & 85261 & 62839 & 1.75 \\
& IP & 277057.5 & 131707 & 145600.5 & 2.13 \\
& FP & 150367.5 & 85511 & 64184 & 1.76 \\
\hline
\end{tabular}

$\mathrm{IP}=$ Improved practice, $\mathrm{FP}=$ Framers' practice

\section{Conclusion and Recommendations}

Considering most of the parameters discussed above, improved cropping pattern wheat (var. BARI Gom26) -Jute (var. O-9897)-T. aman(var. BRRI dhan49) with modern technologiescould be suggested for char areas of 
Netrakona regionof Bangladesh, especially for themarginal farmers. The findings may be used for researcher, extension workers and also for national policy maker for large scale production but further observation is required before dissemination of the technology.

\section{Acknowledgments}

The authors wish to acknowledge the Bangladesh Agricultural University Research System (BAURES) for funding this research project and technical support.

\section{References}

Anowar, M. M., Ferdous, M. Z., \& Mozidul, I. (2012). Determination of nutrient management forPotatoMungbean-T.aman rice cropping pattern.Bangladesh Journal of Progressive Science and Technology, (10), 173-176.

Anowar, M., Parveen, A., Ferdous, Z., Kafi, A. H., Kabir, \& M. E. (2015). Baseline survey for farmer livelihood improvement at farming system research and development, Lahirirhat, Rangpur. International Journal of Business, Management and Social Research, (2), 92-104. https://doi.org/10.18801/ijbmsr.020115.10

Anwar, M., Ferdous, Z., Sarker, M. A., Hasan, A. K., Akhter, M. B., Zaman, M. A. U., Haque, Z., \& Ullah, H. (2017). Employment Generation, Increasing Productivity and Improving Food Security through Farming Systems Technologies in the Monga Regions of Bangladesh. Annual Research Review of Biology, (16), 1-15. https://doi.org/10.9734/ARRB/2017/35645

Datta, A., Shrestha, S., Ferdous, Z., \&Win, C. C. (2015). Strategies for Enhancing Phosphorus Efficiency in Crop Production Systems. In Rakshit, A., Singh, H. B., \& Sen, A. (Eds.), Nutrient Use Efficiency: from Basics to Advances (pp. 59-71). Springer, ISBN 978-81-322-2169-2. https://doi.org/10.1007/978-81-322-2169-2_5

Datta, A., Ullah, H., \& Ferdous, Z. (2017). Water Management in Rice. In Chauhan, B. S., Jabran, K., Mahajan, G. (Eds.), Rice Production Worldwide (pp. 255-277). https://doi.org/10.1007/978-3-319-47516-5_11

Dobermann, A., Nelson, R., Beever, Bergvinson, D., Crowley, E., Denning, G., Giller, K., ... Zhang, F. (2013). Solutions for Sustainable Agriculture and Food Systems, Technical Report for the Post- Development Agenda. Sustainable Development Solutions Network, New York, pp. 1-99.

FAOSTAT (Food and Agriculture Organization Corporate Statistical Database). (2013). FAO, Rome, Italy.

FAOSTAT (Food and Agriculture Organization Corporate Statistical Database) (2014). FAO, Rome, Italy.

Ferdous, Z., Anwar, M., Rahman, M. A., Yasmine, \& Nain, F. J. (2011). Fertilizer management for maizemungbean-T. aman based cropping pattern. Journal of Agroforestry and Environment, (5), 129-132.

Haq, M. Z., Techniques, M., Ali, M., Hasan, M. M., Uddin, M. J., Begum, M., ... Karim, M. R. (2012). Damage and management of Cyclone Sidr-affected homestead tree lantations: a case study from Patuakhali, Bangladesh. Natural Hazards, (64), 1305-1322. https://doi.org/10.1007/s11069-012-0299-x

Haque, M. S. (1998). Integrated nutrient management with inorganic and biofertilizers in legume based cropping patterns. Proc. of the national workshop on integrated nutrient management for crop production and soil fertility. 24-25 March, 1998. BARC, Gazipur. pp. 99-109.

Hossain, M. S., Hossain, A., Sarkar, M. A. R., Jahiruddin, M., Teixeira da Silva, J. A., \& Israil, H. M. (2016). Productivity and soil fertility of the rice-wheat system in the high Ganges River floodplain of Bangladesh is influenced by the inclusion of legumes and manure. Agriculture, Ecosystems and Environment, (218), 40-52. https://doi.org/10.1016/j.agee.2015.11.017

Islam, M. A. (2012a). Pheromone use for insect control: present status and prospect in Bangladesh. International Journal of Agricultural Research, Innovation and Technology, (2), 47-55. https://doi.org/10.3329/ijarit.v2i1.14005

Islam, M. A. (2012b). Knowledge and Practice of Pheromone Technologies: A case Study of a Representative District in Bangladesh. Academic Research International, (2), 55-61.

Islam, M. A., Haq, M. E., Hossain, M. K., \& Hossen, M. S. (2015a). Investigation of formalin and ethepon in some fruits of three local markets of Mymensingh district using gas chromatograph. Journal of the Bangladesh Agricultural University, (13), 7-12. https://doi.org/10.3329/jbau.v13i1.28704

Islam, M. A., Islam, M. Z., \& Hossain, M. K. (2015b). Residual analysis of selected pesticides in cucumber and spinach collected from local markets of Mymensingh sadar. Progressive Agriculture, (26), 38-44. https://doi.org/10.3329/pa.v26i1.24514 
Islam, M. A., Parvin, S., \& Faruk, M. A.(2017a). Impacts of riverbank erosion hazards in the Brahmaputra floodplain areas of Mymensingh in Bangladesh. Progressive Agriculture, (28), 73-83. https://doi.org/10.3329/pa.v28i2.33467

Islam, M. A., Akhter, D., \& Faruk, M. A. (2017). Q-GIS Mapping to Explore the Status of Quality of Drinking Water in Bangladesh. IOSR Journal of Environmental Science, Toxicology and Food Technology (IOSR JESTFT), (11), 17-27.

Khan, M. A. H., Quayyum. M. A., Nazrul, M. I., Sultana, N., \& Mollah, M. R. A. (2005). On-farm evaluation of production potential and economics of Mustard- Rice based improved cropping system. Journal of Sociological Research and Development, (2), 37-42.

Khan, M. A., Hossain, S. M. A., \& Khan, M. A. H. (2006). A study on some selected jute-based cropping patterns at Kishoregonj. Bangladesh Journal of Agricultural Research, (31), 85-95.

Khatun, M. U. S., Alam, M. A. U., Hossain, M. A., Islam, M. K., Anwar, M. M., \& Haque, M. E. (2016). Evaluation of production potential and economics of Radish- Potato/Maize-T. Aman cropping pattern in Rangpur region. Journal of Science, Technology and Environment Informatic, (4), 293-300. https://doi.org/10.18801/jstei.040216.32

Ladha, J. K., Rao, A. N., Raman, A. K., Padre, A. T., Dobermann, A., Gathala, M., ... Noor, S. (2016). Agronomic improvements can make future cereal systems in South Asia far more productive and result in a lower environmental footprint. Global Change Biology, (22), 1054-1074. https://doi.org/10.1111/gcb.13143

Malavia, D. D., Singh, M. P., Vyas, M. M., Patel, J. C., \& Kalaria, K. K. (1986). Production potential and economic feasibility of different crop sequences. Indian Journal of Argonomy, (31), 75-78.

Nazrul, M. I. (2016). On-Farm Assesment of System Productivity of Wheat- Jute- T. aman rice Cropping Pattern in Sylhet Region. Bangladesh Agronomy Journal, (19), 87-94. https://doi.org/10.3329/baj.v19i2.31857

Nazrul, M. I., Shaheb, M. R., Khan, M. A. H., \& Khan, A. S. M. M. R. (2013). On-Farm evaluation of production potential and economic returns of potato-rice based improved cropping system.Bangladesh Agronomy Journal, (16), 41-50.

Neamatollahi, E., Vafabakhshi, J., Jahansuz, M. R., \& Sharifzadeh, F. (2017). Agricultural optimal Cropping pattern determination based on fuzzy system. Fuzzy information and Engineering, (9), 479-491. https://doi.org/10.1016/j.fiae.2017.12.004

Osama, S., Elkholy, M., \& Kansoh, R. M. (2017). Optimization of the cropping pattern in Egypt. Alexandria Engineering Journal, (56), 557-566. https://doi.org/10.1016/j.aej.2017.04.015

Quasem, M. A. (2011). Conversion of Agricultural Land to Non-agricultural Uses in Bangladesh: Extent and Determinants. Bangladesh Development Studies, (34), 59-85.

Reddy, K. (1997). Production potential and economics of different rice (Oryza sativa) based cropping systems in Andhra Pradesh. Indian Journal of Agricultural Science, (67), 551-553.

Rokonuzzaman, M., Rahman, M. A., Yeasmin, M., \& Islam, M. A. (2018). Relationship between precipitation and rice production in Rangpur district. Progressive agriculture, (29), 10-21. https://doi.org/10.3329/pa.v29i1.37476

Soni, P. N., \& Kaur, R. (1984). Studies on production potential of different cropping systems. Indian Journal of Agronomy, (29), 367-378.

Tomer, S. S., \& Tiwari, A. S. (1990). Production potential and economics of different crop sequences. Indian Journal of Agronomy, (35), 30-35.

Verma, S. P., \& Modgal, S. C. (1983). Production potential and economics of fertilizer application as resources constraints in maize, wheat crop sequence. Himachal Journal of Agricultural Research, (9), 89-92.

\section{Copyrights}

Copyright for this article is retained by the author(s), with first publication rights granted to the journal.

This is an open-access article distributed under the terms and conditions of the Creative Commons Attribution license (http://creativecommons.org/licenses/by/4.0/). 